\title{
EFEK MODEL PEMBELAJARAN KOOPERATIF TIPE GROUP INVESTIGATION DAN CREATIVE PROBLEM SOLVING TERHADAP HASIL BELAJAR PEMROGRAMAN DASAR
}

\author{
Musfirati Khasanah, Setiadi Cahyono Putro, Triyanna Widiyaningtyas \\ Universitas Negeri Malang \\ Musfiratiratih@gmail.com
}

\begin{abstract}
ABSTRAK
Tujuan dari penelitian ini adalah untuk megetahui hasil belajar siswa dalam ranah kognitif dan psikomotorik dengan menggunakan model pembelajaran Group Investigation (GI) dan model pembelajaran Creative Problem Solving (CPS) berbantuan handout pada mata pelajaran Pemrograman Dasar kelas $X$ Program Keahlian Multimedia.Penelitian ini menggunakan rancangan penelitian eksperimen pretest posttest dengan pendekatan kuantitatif. Hasil dari penelitian diperoleh (1) rata-rata hasil belajar kelas X MM 1 dalam ranah kognitif sebesar 70,303 dan ranah psikomotorik sebesar 70,303, sedangkan rata-rata hasil belajar kelas X MM 2 dalam ranah kognitif sebesar 79,375 dan ranah psikomotorik sebesar 77,031 (2) Hasil uji t dalam ranah kognitif dengan menerapkan model pembelajaran Group Investigation dan Creative Problem Solving sebesar 0,028. Hasil uji $t$ dalam ranah psikomotorik dengan menerapkan model pembelajaran Group Investigation sebesar 0,046 dan Creative Problem Solving sebesar 0,045. Berdasarkan hasil tersebut, maka terdapat perbedaan dalam ranah psikomotorik diantara keduanya.
\end{abstract}

Kata Kunci : Group Investigation, Creative Problem Solving, hasil belajar

\section{ABSTRACT}

The purpose of this research is to know the students learning outcomes in the cognitive and psychomotor domains by using Group Investigation (GI) model and Creative Problem Solving (CPS) learning model with handout assistance on the subjects of Basic Programming Class $X$ Program Multimedia Expertise. This research uses the design experimental pretest posttest model research with quantitative approach. The result of the research is (1) the average of learning result of class X MM 1 in the cognitive domain is 70,303 and psychomotor aspect is 70,303 , while the mean of learning result of class X MM 2 in the cognitive domain is 79,375 and psychomotor domain is 77,031 (2) The result of $t$ test in cognitive domain by applying Group Investigation and Creative Problem Solving model is 0,028 . The result of $t$ test in the psychomotor realm by applying Group Investigation model 0.046 and Creative Problem Solving 0.045 . Based on these results, there is a difference in the psychomotor domain between the two.

Keywords: Group Investigation, Creative Problem Solving, learning outcomes

\section{PENDAHULUAN}

Pendidikan merupakan usaha sadar, terencana dan diupaya-kan untuk mendorong siswa aktif dalam mengembangkan potensi diri (Supriadie \& Darmawan, 2012). Pendidikan hakikatnya proses membangun dengan dilandasi tiga aspek, yang meliputi: aspek afektif (sikap), aspek kognitif (pengetahuan), dan aspek psikomotorik (keterampilan). Aspek afektif adalah kemampuan yang berkaitan dengan sikap siswa di dalam kelas. Aspek kognitif adalah kemampuan yang berkaitan dengan kemampuan berfikir siswa ketika 
proses pembelajaran. Aspek psikomotorik adalah kemampuan yang berkaitan dengan keterampilan dan tindakan siswa ketika menyelesaikan suatu masalah. Keberhasilan pencapaian aspek-aspek tersebut menjadi tujuan dari pendidikan, yaitu memberikan output yang berkualitas dalam menghadapi dunia kerja.

Hasil observasi dan wa-wancara dengan guru mata pelajaran Pemrograman Dasar di SMKN 11 Malang, guru telah berupaya menerapkan model pembelajaran berkelompok yaitu Group Investigation. Model pembelajaran Group Investigation merupakan model pembelajaran yang kompleks dalam pembelajaran kelompok yang mengharuskan siswa untuk menggunakan kemampuan berfikir dengan serius (Huda, 2015). Kelebihan model pembelajaran Group Investigation dibagi menjadi tiga yaitu secara pribadi meliputi semangat ber-inisiatif, sosial meliputi peningkatan proses bekerjasama, dan akademis meliputi mengembangkan ke-terampilan (mu, 2017). Sintak model pembelajaran Group Investigation meliputi seleksi topik, organisasikan dalam kelompok yang berorientasi pada tugas (task oriented groups), perencanaan kerja, implementasi, analisis dan sintesis, penyajian hasil akhir, dan evaluasi (Huda, 2015).

Akan tetapi, upaya guru dalam meningkatkan pembelajaran yang kondusif, masih memunculkan masalah bagi siswa. Masalah-masalah yang dihadapi siswa ketika proses pembelajaran Pemrograman Dasar, meliputi kurangnya ketertarikan siswa dalam memahami materi, sekitar 5 atau 6 siswa tidak lulus KKM ketika ulangan harian, dan nilai UTS hampir 50\% kelas tidak melampaui KKM. Selain itu, beberapa kelompok tidak me-ngerjakan tugas maupun terlambat mengerjakan tugas, dan banyak siswa yang ramai ketika pembelajaran kelompok berlangsung, serta siswa cenderung kurang aktif dalam menanggapi suatu materi.

Penelitian serupa yang teridentifikasi oleh Putro \& Desynatria (2016) tentang hasil belajar siswa memberikan kesimpulan bahwa penggunaan model pembelajaran dan tingkat inisiatif dapat mempengaruhi hasil belajar siswa pada Pemrograman Web. Selain itu, hasil penelitian Lestari (2014) menunjukkan adanya perbedaan hasil belajar siswa dengan menggunakan model pembelajaran TPS dan GI. Kedua penelitian tersebut mendukung hasil penelitian dari Purnamasari \& Putro (2012) tentang pengaruh faktor keaktifan dan variasi metode pembelajaran terhadap hasil belajar dasar Pemrograman Pascal.

Berdasarkan permasalahan dan penelitian serupa, melatar-belakangi peneliti untuk mem-bandingkan model pembelajaran tipe kooperatif dengan sistem kerja kelompok, yaitu Creative Problem Solving. Model pembelajaran Creative Problem Solving merupakan suatu model 
pem-belajaran yang melakukan pemusatan pada pengajaran dan keterampilan pemecahan masalah yang diikuti dengan penguatan keterampilan (Mutiara, Suyanto \& Abdurrahman, 2014).

Kelebihan dari model pembelajaran Creative Problem Solving adalah mendorong siswa untuk lebih memahami suatu masalah. Dorongan tersebut dapat melatih siswa untuk lebih cepat dalam mencari solusi atau penyelesaiannya. Selan itu, memudahkan siswa untuk mengetahui konsep dan menyelesaikan soal-soal yang berkaitan dengan materi dan membantu keberhasilan suatu pembelajaran melalui kinerja yang baik, serta mendukung keterbukaan siswa dalam memahami materi (Mutiara, Suyanto, \& Abdurrahman, 2014). Langkah-langkah model pembelajaran Creative Problem Solving meliputi memahami tantangan, menghasilkan ide, mempersiapkan aksi, dan merencanakan pendekatan (Isaksen, Dorval \& Treffinger, 2000).

Oleh karena itu, tujuan dari penelitian ini adalah mengetahui hasil belajar dalam ranah kognitif dan psikomotorik pada mata pe-lajaran Pemrograman Dasar dengan menggunakan model pembelajaran Group Investigation dan Creative Problem Solving, yang keduanya berbantuan handout.

\section{METODE}

Penelitian dilakukan pada mata pelajaran Pemrograman Dasar di kelas X Multimedia SMK Negeri 11 Malang. Penelitian ini menggunakan rancangan penelitian eksperimen pretest posttest dengan pendekatan kuantitatif. Subjek penelitian adalah kelas $\mathrm{X}$ MM 1 yang berjumlah 33 siswa dan kelas $X$ MM 2 yang berjumlah 32 siswa. Kedua kelas akan diberikan perlakuan yang sama dari segi materi dan handout, akan tetapi model dan strategi pembelajaran yang digunakan berbeda. Kelas ekspe-rimen 1 (X $M M$ 1) diberi perlakuan dengan model pembelajaran Creative Problem Solving (CPS) berbantuan handout dan kelas eksperimen 2 (X MM 2) diberi perlakuan dengan model pembelajaran Group Investigation (GI) berbantuan handout.

Tabel 1. Rancangan Penelitian

\begin{tabular}{lll}
\hline $\begin{array}{l}\text { Model } \\
\text { Pembelajaran }\end{array}$ & $\begin{array}{l}\text { Nilai } \\
\text { Kognitif }\end{array}$ & $\begin{array}{l}\text { Nilai } \\
\text { Psikomotorik }\end{array}$ \\
\hline Model A & K1 & P1 \\
\hline Model B & K2 & P2 \\
\hline
\end{tabular}

Keterangan

$\overline{\mathrm{K} 1}$ : Rata-rata ranah kognitif model GI berbantuan handout

$\overline{\mathrm{K} 2}$ : Rata-rata ranah kognitif model CPS berbantuan handout

$\overline{\mathrm{P} 1}$ : Rata-rata ranah psikomotorik GI model berbantuan handout 
$\overline{\mathrm{P} 2}$ : Rata-rata ranah psiko-motorik model CPS ber-bantuan handout

Pada Tabel 1 dapat diketahui bahwa model A merupakan model pembelajaran Group Investigation, sedangkan model B adalah model Creative Problem Solving. Variabel yang diukur adalah hasil belajar dalam ranah kognitif dan hasil belajar dalam ranah psikomotorik. Model pembelajaran yang dibandingkan untuk mengukur hasil belajar adalah model pembelajaran Group Investigation dan model pembelajaran Creative Problem Solving.

Instrumen penelitian untuk mengukur variabel yang tersedia dan telah teruji validitas dan reliabilitasnya (Sugiyono, 2015) meliputi instrumen perlakuan dan instrumen pengukuran. Instrumen perlakuan diantaranya silabus, RPP, handout, jobsheet, dan powerpoint. Instrumen pengukuran meliputi kisikisi soal, soal posttest, dan lembar observasi. Pengukuran terhadap instrumen-instrumen penelitian tersebut meliputi uji validitas, uji reliabilitas, uji kesukaran butir soal dan uji daya beda. Uji validitas merupakan perhitungan untuk memperoleh data yang valid (Arikunto, 2012). Uji validitas meliputi uji validitas isi, validitas konstruk dan validitas butir. Soal yang diuji adalah soal posttest yang terdiri dari 28 soal pilihan ganda. Uji validitas pada penelitian ini, diteliti dan dipertimbangkan oleh tim ahli yaitu Dr. Setiadi C.P., M.Pd., M.T (Dosen pembimbing I), Triyanna Widiyaningtyas, S.T., M.T (Dosen Pembimbing II dan Rizki Isfrandi Wijaya (Guru Pemrograman Dasar SMKN 11 Malang).

Uji Reliabilitas merupakan instrumen tes yang memberikan hasil yang tetap (Arikunto, 2010). Reliabilitas dihitung dengan menggunakan SPSS 25. Hasil perhitungan reliabilitas sebesar 0,722. Berdasarkan pengelompokan interpretasi nilai $r$ menurut Arikunto (2012), hasil reliabilitas termasuk kategori cukup. Tahapan berikutnya adalah uji kesukaran butir soal. Penentuan uji kesukaran butir soal dengan menggunakan SPSS 25. Perolehan kriteria indeks kesukaran butir soal berdasarkan soal sukar, soal sedang dan soal mudah (Arikunto, 2010), menghasilkan 2 soal sukar, 15 soal sedang dan 5 soal mudah. Tahapan terakhir adalah uji daya beda. Uji daya beda menghasilkan 3 soal ditolak, 2 soal diperbaiki, 3 soal diterima dan diperbaiki, serta 20 soal diterima.

Analisis statistik yang digunakan untuk mengetahui nilai setiap variabel berdistribusi normal atau tidak adalah uji normlalitas. Pada penelitian ini uji normalitas menggunakan SPSS 25 berdasarkan hasil dari Kolmogorov-Smirnov, yaitu distribusi normal apabila nilai probabilitas $($ Asymp) $>0,05$. Ketika 
data telah terdistribusi normal, berikutnya penentuan data perolehan homogen atau tidak dengan sampel. Syarat pernyataan homogen apabila signifikansi $(p)>$ 0,05 . Selanjutnya, analisa data untuk mengetahui ada atau tidaknya perbedaan hasil belajar ketika menggunakan model pembelajaran Group Investigation dan model pembelajaran Creative Problem Solving yaitu uji hipotesis. Pengujian hipotesis dengan menggunakan uji-t. Hipotesis yang diuji adalah:

$\mathrm{H}_{\mathrm{o1}}$ : Tidak terdapat perbedaan hasil belajar yang signifikan dalam ranah kognitif antara model pembelajaran creative problem solving berbantuan handout dengan model pembelajaran group investigation berbantuan handout

$\mathrm{H}_{\mathrm{o} 2}$ : Tidak terdapat perbedaan hasil belajar yang signifikan dalam ranah psikomotorik antara model pembelajaran creative problem solving berbantuan handout dengan model pembelajaran group investigation berbantuan handout

$\mathrm{H}_{\mathrm{a} 1}$ : Terdapat perbedaan hasil belajar yang signifikan dalam ranah kognitif antara model pembelajaran creative problem solving berbantuan handout dengan model pembelajaran group investigation berbantuan handout
$\mathrm{H}_{\mathrm{a} 2}$ : Terdapat perbedaan hasil belajar yang signifikan dalam ranah psikomotorik antara model pembelajaran creative problem solving berbantuan handout dengan model pembelajaran group investigation berbantuan handout

Kriteria pengujian hipotesis adalah jika nilai signifikansi $p>0,05$ atau $\mathrm{F}_{\text {hitung }}<\mathrm{F}_{\text {tabel, }}$ maka $\mathrm{H}_{\mathrm{o}}$ diterima dan $H_{a}$ ditolak (tidak adanya perbedaan yang signifikan antara kedua model pembelajaran). Jika nilai signifikansi $\mathrm{p}<0,05$ atau $\mathrm{F}_{\text {hitung }}>$

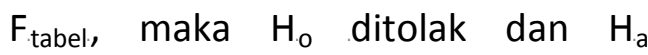
diterima (adanya perbedaan yang signifikan antara kedua model pembelajaran).

\section{HASIL}

Hasil belajar yang diukur dalam penelitian ini adalah hasil belajar kognitif melalui posttest dan hasil belajar psikomotorik melalui observasi. Pengukuran kedua ranah tersebut, diawali dengan pengukuran kemampuan rata-rata awal siswa yaitu dengan melakukan pretest. Perolehan nilai rata-rata pretest kelas X MM 1 dan kelas X MM 2 dapat dilihat pada Gambar 1.

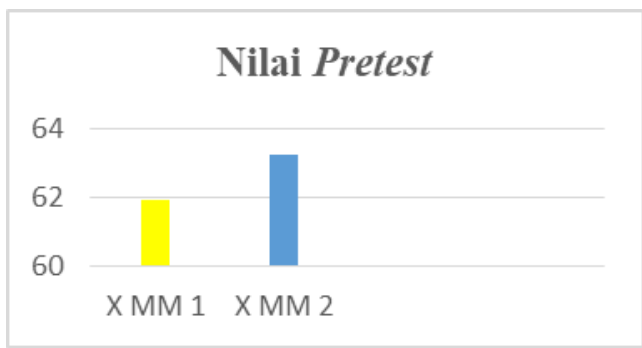


Gambar 1. Grafik Nilai Rata-Rata Pretest Kelas X MM 1 dan Kelas X MM 2 Berdasarkan Gambar 1 ratarata nilai pretest pada kelas eksperimen 1 (X MM 1) sebesar 61,93 dan kelas eksperimen 2 (X MM 2) sebesar 63,25. Tahapan berikutnya adalah uji normalitas, uji homogenitas dan uji hipotesis. Hasil dari uji normalitas hasil pretest kedua kelas eksperimen yaitu kelas eksperimen 1 sebesar 0,140 dan kelas eksperimen 2 sebesar 0,098. Hasil uji normalitas kedua kelas menunjukkan lebih dari 0,05 , sehingga data yang diperoleh dapat disimpulkan normal. Hasil uji homogenitas kedua kelas adalah 0,344, karena 0,344 >0,05 maka data tersebut homogen. Tahapan terakhir yaitu uji hipotesis, kelas eksperimen 1 menunjukkan nilai signifikansi 0,314 dan kelas eksperimen 2 menunjukkan nilai signifikansi 0,308. Kedua nilai signifikansi hasil perhitungan independent sample test lebih dari 0,05 , sehingga dapat disimpulkan bahwa tidak terdapat perbedaan nilai diantara kedua kelas.

Pengukuran kedua yaitu perhitungan hasil belajar siswa dalam ranah kognitif setelah diberi perlakuan. Diketahui rata-rata hasil belajar kelas X MM 1 dalam ranah kognitif sebesar 70,303 sedangkan rata-rata hasil belajar kelas X MM 2 dalam ranah kognitif sebesar 79,375. Berikut hasil ranah kognitif dari kelas eksperimen 1 dan kelas eksperimen 2.
Tabel 2. Pengelompokkan Rata-Rata Ranah Kognitif Kelas Eksperimen 1

\begin{tabular}{|c|c|c|c|}
\hline Kategori & $\begin{array}{c}\text { Interval } \\
\text { Ideal }\end{array}$ & Frek & $\begin{array}{c}\text { Persentas } \\
\text { e }\end{array}$ \\
\hline ST & $86-100$ & 4 & $12,12 \%$ \\
\hline $\mathrm{T}$ & $76-85$ & 5 & $15,15 \%$ \\
\hline$S$ & $66-75$ & 9 & $27,27 \%$ \\
\hline $\mathrm{R}$ & $56-65$ & 9 & $27,27 \%$ \\
\hline SR & $40-55$ & 6 & $18,18 \%$ \\
\hline \multicolumn{2}{|c|}{ Total } & 33 & $100 \%$ \\
\hline
\end{tabular}

Berdasarkan Tabel 2 dapat diketahui bahwa rata-rata hasil belajar siswa dalam ranah kognitif dengan menggunakan model pembelajaran Group Investigation menghasilkan persentase kategori sangat tinggi $12,12 \%$, kategori tinggi $15,15 \%$, kategori sedang $27,27 \%$, kategori rendah $27,27 \%$, dan kategori sangat rendah $18,18 \%$.

Tabel 1. Pengelompokkan Rata-Rata Ranah Kognitif Kelas Eksperimen 2

\begin{tabular}{|c|c|c|c|}
\hline Kategori & $\begin{array}{c}\text { Interval } \\
\text { Ideal } \\
\end{array}$ & Frek & Persentase \\
\hline ST & $86-100$ & 13 & $40,62 \%$ \\
\hline $\mathrm{T}$ & $76-85$ & 7 & $21,87 \%$ \\
\hline$S$ & $66-75$ & 4 & $12,5 \%$ \\
\hline $\mathrm{R}$ & $56-65$ & 4 & $12,5 \%$ \\
\hline SR & $40-55$ & 4 & $12,5 \%$ \\
\hline \multicolumn{2}{|c|}{ Total } & 32 & $100 \%$ \\
\hline
\end{tabular}

Berdasarkan Tabel 3 dapat diketahui bahwa rata-rata hasil belajar siswa dalam ranah kognitif dengan perolehan persentase kategori sangat tinggi $40,62 \%$, kategori tinggi 21,87\%, kategori sedang $12,5 \%$, kategori rendah $12,5 \%$, dan kategori sangat rendah $12,5 \%$.

Grafik perbandingan hasil belajar dalam ranah kognitif pada kelas eksperimen 1 yang 
menggunakan model pembelajaran Group Investigation berbantuan handout dengan kelas eksperimen 2 menggunakan model pembelajaran Creative Problem Solving berbantuan handout dapat dilihat pada Gambar 2.

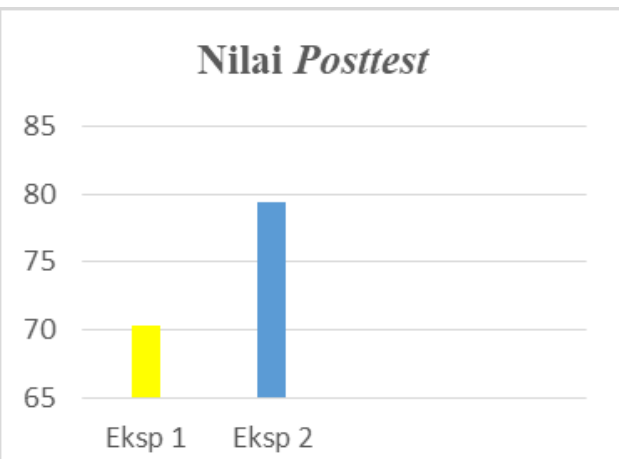

Gambar 1. Grafik Nilai Rata-Rata Posttest Kelas Eksperimen 1 dan Kelas Eksperimen 2

Grafik dari gabungan perbedaan rata-rata ranah kognitif pretest dan posttest dapat dilihat pada Gambar 3.

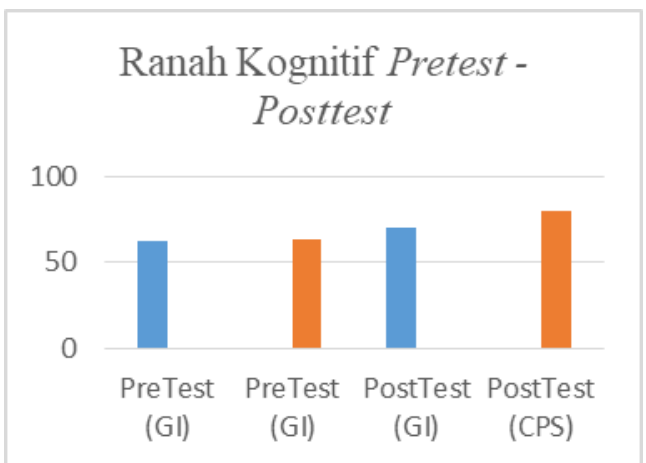

Gambar 3. Grafik Pretest-Posttest Ranah Kognitif Kelas Eksperimen 1 dan Kelas Eksperimen 2

Pada Gambar 3 dapat diketahui bahwa grafik nilai pretest dengan model pembelajaran Group Investigation pada kelas eksperimen 1 menunjukkan hampir sebanding dengan nilai pretest dengan model pembelajaran Group Investigation pada kelas eksperimen 2. Grafik tersebut menunjukkan bahwa nilai kedua kelas memiliki kemampuan rata-rata yang hampir sama. Perlakuan setelah mengetahui terdapatnya kesamaan rata-rata pada kedua kelas adalah dengan memberikan posttest. Pada kelas eksperimen 1 posttest diberikan dengan menerapkan model pembelajaran Group Investigation berbantuan handout, sedangkan pada kelas eksperimen 2 posttest diberikan dengan menerapkan pembelajaran Creative Problem Solving berbantuan handout. Hasil yang diperoleh yaitu terjadi peningkatan terhadap kedua kelas eksperimen.

Pengukuran ketiga yaitu pengukuran ranah psikomotorik setelah diberi perlakuan pada kedua kelas. Diketahui rata-rata hasil belajar kelas $\mathrm{X} \quad \mathrm{MM} \quad 1$ dalam ranah psikomotorik sebesar 70,303, sedangkan rata-rata hasil belajar kelas $X \quad M M \quad 2$ dalam ranah psikomotorik sebesar 77,031. Berikut hasil ranah psikomotorik dari kelas eksperimen 1 dan kelas eksperimen 2.

Tabel 4. Pengelompokkan Rata-Rata Ranah Psikomotorik Kelas Eksperimen 1

\begin{tabular}{|c|c|c|c|}
\hline Kategori & $\begin{array}{c}\text { Interval } \\
\text { Ideal }\end{array}$ & Frek & Persentase \\
\hline ST & $84-100$ & 8 & $24,24 \%$ \\
\hline $\mathrm{T}$ & $77-83$ & 3 & $9,09 \%$ \\
\hline$S$ & $69-76$ & 6 & $18,18 \%$ \\
\hline$R$ & $62-68$ & 8 & $24,24 \%$ \\
\hline SR & $50-61$ & 8 & $24,24 \%$ \\
\hline \multicolumn{2}{|c|}{ Total } & 33 & $100 \%$ \\
\hline
\end{tabular}




Berdasarkan Tabel 4 dapat
diketahui bahwa rata-rata hasil
belajar siswa dalam ranah
psikomotorik dengan perolehan
persentase kategori sangat tinggi
$24,24 \%$ kategori tinggi $9,09 \%$,
kategori sedang 18,18\%, kategori
rendah 24,24\%, kategori sangat
rendah 24,24\%.

Tabel 5. Pengelompokkan Rata-Rata Ranah Psikomotorik Kelas Eksperimen 2

\begin{tabular}{|c|c|c|c|}
\hline Kategori & $\begin{array}{c}\text { Interval } \\
\text { Ideal }\end{array}$ & Frek & Persentase \\
\hline ST & $84-100$ & 12 & $37,5 \%$ \\
\hline $\mathrm{T}$ & $77-83$ & 4 & $12,5 \%$ \\
\hline$S$ & $69-76$ & 7 & $21,8 \%$ \\
\hline $\mathrm{R}$ & $62-68$ & 5 & $15,6 \%$ \\
\hline SR & $50-61$ & 4 & $12,5 \%$ \\
\hline \multicolumn{2}{|c|}{ Total } & 32 & $100 \%$ \\
\hline
\end{tabular}

Berdasarkan Tabel 5 dapat diketahui bahwa rata-rata hasil belajar siswa dalam ranah psikomotorik dengan perolehan persentase kategori sangat tinggi $37,5 \%$, kategori tinggi $12,5 \%$, kategori sedang $21,8 \%$, kategori rendah $15,6 \%$, kategori sangat rendah $12,5 \%$.

Grafik perbandingan hasil belajar dalam ranah psikomotorik pada kelas eksperimen 1 yang menggunakan model pembelajaran Group Investigation berbantuan handout dengan kelas eksperimen 2 menggunakan model pembelajaran Creative Problem Solving berbantuan handout dapat dilihat pada Gambar 4.

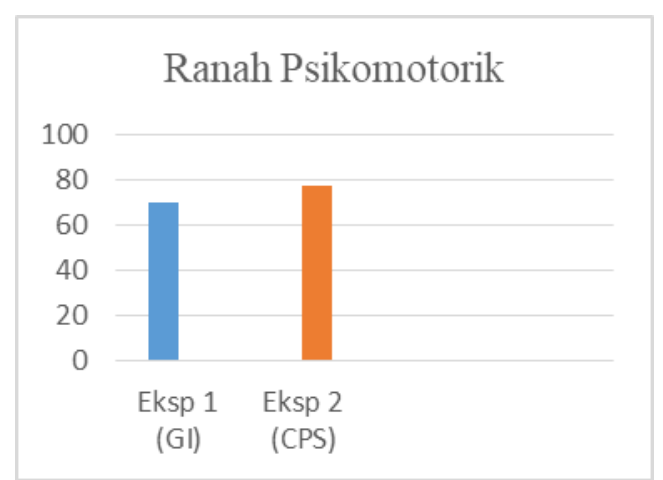

Gambar 4. Grafik Ranah Psikomotorik Kelas Eksperimen 1 dan Kelas Eksperimen 2

Pada Gambar 4 dapat diketahui bahwa grafik nilai psikomotorik pada kelas eksperimen 2 yang menggunakan model pembelajaran Creative Problem Solving berbantuan handout lebih tinggi dibandingkan dengan grafik nilai psikomotorik pada kelas eksperimen 1 yang menggunakan model pembelajaran Group Investigation berbantuan handout. Berdasarkan grafik tersebut dapat ditarik kesimpulan bahwa penggunaan kedua model pembelajaran dapat meningkatkan dan mengasah keterampilan siswa dalam menyelesaikan suatu permasalahan. Keefektifan penggunaan model pembelajaran untuk menumbuhkan keterampilan siswa lebih cenderung pada penerapan model pembelajaran Creative Problem Solving berbantuan handout dibandingkan model pembelajaran Group Investigation berbantuan handout.

Hasil uji normalitas dalam ranah kognitif dan psikomotorik pada kedua kelas eksperimen dapat dilihat pada Tabel 6 dan Tabel 7. 
Tabel 6. Hasil Perhitungan Uji Normalitas Kognitif

\begin{tabular}{lllll}
\hline \multirow{2}{*}{ Kelas } & \multicolumn{3}{c}{ Kolmogoro-Smirnov } \\
\cline { 3 - 5 } & & Statistic & Df & Sig \\
\hline \multirow{2}{*}{ Tes } & Eksperimen & 0,144 & 33 & 0,080 \\
& 1 & & & \\
\hline \multirow{4}{*}{} & Eksperimen & 0,143 & 32 & 0,095 \\
& 2 & & & \\
\hline
\end{tabular}

Hasil uji normalitas rata-rata hasil belajar dalam ranah kognitif dari kedua kelas eksperimen diperoleh nilai signifikansi lebih dari 0,05. Signifikansi lebih dari 0,05 menujukkan data yang diperoleh normal, sehingga hasil dari kedua kelas eksperimen dapat dikatakan normal. Pada kelas eksperimen 1 nilai signifikansinya 0,080 dan kelas eksperimen 2 nilai signifikansinya 0,095 .

Tabel 7. Hasil Perhitungan Uji Normalitas Psikomotorik

\begin{tabular}{lllll}
\hline \multirow{2}{*}{ Kelas } & \multicolumn{3}{l}{ Kolmogoro-Smirnov } \\
\cline { 3 - 5 } & & Statistic & Df & Sig \\
\hline \multirow{2}{*}{ Tes } & Eksperimen & 0,145 & 33 & 0,075 \\
& 1 & & & \\
\hline \multirow{3}{*}{$\begin{array}{l}\text { Eksperimen } \\
2\end{array}$} & 0,122 & 32 & 0,200 \\
& & & \\
\hline
\end{tabular}

Hasil uji normalitas rata-rata hasil belajar dalam ranah psikomotorik dari kedua kelas eksperimen diperoleh nilai signifikansi lebih dari 0,05. Signifikansi lebih dari 0,05 menujukkan data yang diperoleh normal, sehingga hasil dari kedua kelas eksperimen dapat dikatakan normal. Pada kelas eksperimen 1 nilai signifikansinya 0,075 dan kelas eksperimen 2 nilai signifikansinya 0,200.
Uji hipotesis dilakukan untuk mengetahui apakah hipotesis awal diterima atau ditolak. Hasil uji hipotesis menggunakan uji - $\mathrm{t}$ dapat dilihat pada Tabel 8 dan Tabel 9.

Tabel 8. Hasil Uji Hipotesis dalam Ranah

\begin{tabular}{ccc}
\multicolumn{2}{c}{ Kognitif } & \\
\hline Kelas & N & $\begin{array}{c}\text { Sig (2- } \\
\text { tailed) }\end{array}$ \\
\hline $\begin{array}{c}\text { X MM 1 } \\
\text { (Kelas Eksperimen 1) } \\
\text { X MM 2 }\end{array}$ & 33 & 0,028 \\
$\begin{array}{c}\text { (Kelas Eksperimen 2) } \\
\text { (Kel }\end{array}$ & 32 & 0,028 \\
\hline
\end{tabular}

Pada hipotesis 1 berdasarkan perhitungan pada Tabel 8 dapat diketahui signifikansi kelas eksperimen 1 sebesar 0,028 dan kelas eksperimen 2 sebesar 0,028. Signifikansi tersebut menunjukkan bahwa 0,028 $<0,05$ dan 0,028 $<0,05$ sehingga keduanya menghasilkan $\mathrm{H}_{01}$ ditolak dan $\mathrm{H}_{\text {a1 }}$ diterima. Hipotesis dari penelitian ini berkaitan dengan ranah kognitif yaitu kelas eksperimen 1 dan kelas eksperimen 2 memunculkan hipotesis bahwa terdapat perbedaan diantara kedua kelas. Perbedaan tersebut merupakan pengaruh penerapan model pembelajaran Group Investigation pada kelas eksperimen 1 dan Creative Problem Solving pada kelas eksperimen 2.

Tabel 9. Hasil Uji Hipotesis dalam Ranah Psikomotorik

\begin{tabular}{lcc}
\hline Kelas & N & $\begin{array}{l}\text { Sig (2- } \\
\text { tailed) }\end{array}$ \\
\hline $\begin{array}{l}\text { X MM 1 } \\
\text { (Kelas Eksperimen 1) }\end{array}$ & 33 & 0,046 \\
$\begin{array}{l}\text { X MM 2 } \\
\text { (Kelas Eksperimen 2) }\end{array}$ & 32 & 0,045 \\
\hline
\end{tabular}


Pada hipotesis 2 berdasarkan perhitungan pada Tabel 9 dapat diketahui signifikansi kelas eksperimen 1 sebesar 0,046 dan kelas eksperimen 2 sebesar 0,045. Signifikansi tersebut menunjukkan bahwa 0,046 0,05 dan 0,045 0,05 sehingga keduanya menghasilkan $\mathrm{H}_{\mathrm{o1}}$ ditolak dan $\mathrm{H}_{\mathrm{a} 1}$ diterima. Hipotesis dari penelitian ini berkaitan dengan ranah kognitif yaitu kelas eksperimen 1 dan kelas eksperimen 2 memunculkan hipotesis bahwa terdapat perbedaan diantara kedua kelas. Perbedaan tersebut merupakan pengaruh penerapan model pembelajaran Group Investigation pada kelas eksperimen 1 dan Creative Problem Solving pada kelas eksperimen 2.

\section{PEMBAHASAN}

Model pembelajaran Group Investigation menjadi salah satu model pembelajaran yang dapat meningkatkan aktivitas dan kemampuan kerjasama antar siswa (Irwan \& Sani, 2015). Selain itu, model Group Investigation dapat menjadi alternatif dalam meningkatan hasil belajar siswa. Metode yang dilakukan yaitu dengan menentukan investigasi suatu masalah. Salah satu model pembelajaran yang juga memfokuskan pada penyelesaian terhadap suatu masalah yaitu Creative Problem Solving.

Model pembelajaran Creative Problem Solving merupakan model pembelajaran pemecahan suatu masalah secara kreatif (Totiana, Susanti \& Redjeki, 2012). Pada penelitian ini, penerapan model pembelajaran Group Investigation dan Creative Problem Solving disertai dengan handout. Harapan dari penggunaan handout dapat membantu meningkatkan semangat belajar siswa dalam mata pelajaran Pemrograman Dasar di luar jam sekolah.

Pada pertemuan pertama, dalam pelaksanaan model pembelajaran Group Investigation di kelas $X$ MM 1 masih banyak siswa yang bingung dan ramai ketika pembelajaran berlangsung. Pada pertemuan berikutnya, siswa cenderung semangat dalam belajar dan menyelesaikan permasalahan secara berkelompok karena siswa sudah memahami alur dari investigasi permasalahan. Pelaksanaan model pembelajaran Creative Problem Solving di kelas $\mathrm{X}$ MM 2 menunjukkan hasil yang berbeda-beda. Pada pertemuan pertama siswa cenderung kurang aktif dalam ber-tanya, menjawab maupun me-nanggapi suatu permasalahan. Pada pertemuan berikutnya siswa lebih aktif dalam bertanya, menjawab dan menanggapi permasalahan. Penerapan metode Creative Problem Solving tersebut sudah dipahami siswa sehingga siswa mengerti langkah apa yang dilakukan ketika memecahkan suatu permasalahan.

Model pembelajaran Group Investigation merupakan salah satu 
tipe pembelajaran kooperatif yang melibatkan seluruh siswa dan melibatkan tutor sebaya dalam implementasinya (Wildanisnaini, Susanti \& Haryono, 2015). Implementasi model pembelajaran Group Investigation yaitu guru memberikan suatu permasalahan yang harus dipahami oleh setiap kelompok. Tahapan selanjutnya, setiap kelompok melakukan investigasi terhadap permasalahan.

Pada tahap akhir terdapat evaluasi kepada setiap kelompok untuk melihat tingkat pemahaman siswa terhadap materi. Penerapan model pembelajaran kooperatif lainnya adalah model pembelajaran Creative Problem Solving. Model pembelajaran Creative Problem Solving merupakan model pembelajaran yang dapat meningkatkan penguasaan konsep dan keterampilan dalam menyelesaikan permasalahan (Mayasari, Halim \& Ilyas, 2013). Implementasi dari model pembelajaran Creative Problem Solving bersifat menyeluruh terhadap kemampuan intelektual siswa, sehingga kelompok belajar dapat dilakukan secara acak. Metode yang digunakan adalah menganalisis suatu permasalahan dan keterampilan dalam menyelesaikan suatu permasalahan.

Pada pertemuan pertama di kelas X MM 1 dengan menerapkan model pembelajaran Group Investigation, siswa terlihat sangat bergantung dengan kelompoknya.
Ketika pelaksanaan penyelesaian dengan kelompok, hanya beberapa siswa yang aktif berpendapat memecahkan masalah. Pada pertemuan berikutnya, siswa yang cenderung aktif membantu teman satu kelompoknya untuk memahami permasalahan (tutor sebaya). Permasalahan pada pertemuan pertama di kelas X MM 2 hampir sama dengan di kelas X MM 1. Siswa cenderung bergantung dengan teman sekelompok yang memiliki kemampuan lebih tinggi. Pada pertemuan berikutnya dengan menerapkan model pembelajaran Creative Problem Solving, siswa cenderung terampil dalam menyelesaikan permasalahan, bahkan siswa mampu mengaitkan penyelesaian suatu permasalahan dengan kehidupan sehari-hari.

\section{SIMPULAN}

Simpulan dari penelitian ini sebagai berikut : Rata-rata hasil belajar kelas X MM 1 dalam ranah kognitif sebesar 70,303 dan ranah psikomotorik sebesar 70,303, sedangkan rata-rata hasil belajar kelas X MM 2 dalam ranah kognitif sebesar 79,375 dan ranah psikomotorik sebesar 77,031. Terdapat perbedaan hasil belajar yang signifikan dalam ranah kognitif antara siswa yang diberi perlakuan model pembelajaran Group Investigation dengan model pembelajaran Creative Problem Solving. Hasil yang diperoleh dari 
model pembelajaran Group Investigation adalah 0,028 dan hasil pemahaman siswa dan menciptakan suasana kelas yang kondusif.

dari model pembelajaran Creative Problem Solving adalah 0,028. Terdapat perbedaan hasil belajar yang signifikan dalam ranah psikomotorik antara siswa yang diberi perlakuan model pembelajaran Group Investigation dengan model pem-belajaran Creative Problem Solving. Hasil yang diperoleh dari model pembelajaran Group Investigation adalah 0,046 dan hasil dari model pembelajaran Creative Problem Solving adalah 0,045.

Berdasarkan hasil penelitian dan pembahasan, saran yang dapat disampaikan adalah : Guru dapat menerapkan model pembelajaran Creative Problem Solving berbantuan handout pada proses pembelajaran Pemrograman Dasar. Alasan dari pernyataan tersebut adalah perbedaan peningkatan hasil belajar kognitif dan psikomotorik yang lebih tinggi dibandingkan menggunakan model pembelajaran Group Investigation.

Selain itu, guru dapat menerapkan model pembelajaran Creative Problem Solving dalam pembelajaran dengan sistem kelompok. Pada penelitian selanjutnya diharapkan mampu menerapkan model pembelajaran ataupun media pembelajaran yang lebih baik. Tujuan dari semakin beragamnya model pembelajaran menjadi sarana dalam meningkatkan

\section{DAFTAR RUJUKAN}

Arikunto, S. 2010. Prosedur Penelitian Suatu Pendekatan Praktik. Cetakan ke 14. Jakarta : Rineka Cipta

Arikunto, S. 2012. Prosedur Penelitian Suatu Pendekatan Praktik. Jakarta : Rineka Cipta

Huda, M. 2015. Model-Model Pengajaran dan Pembelajaran. Yogyakarta : Pustaka Pelajar

Irwan, N., Sani, R.A. 2015. Efek Model Pembelajaran Kooperatif Tipe Group Investigation dan Teamwork Skills terhadap Hasil Belajar Fisika. Vol (4) No 1. Tersedia di https://media.neliti.com/media /publications/120403-IDnone.pdf

Isaksen, S.G., Dorval, K.B., Treffinger, D.J. 2000. Creative Problem Solving: An Introduction. Tersedia di: http://www.creativelearning.c om-/PDF-/CPS-Version61.pdf

Lestari, N.M. 2014. Perbedaan Hasil Belajar Siswa dengan Menggunakan Model Pembelajaran Kooperatif Tipe Think Pair Share (TPS) dan Tipe Group Investigation (GI) pada Mata Pelajaran Sistem Operasi Kelas $X$ Multimedia (MM) di SMKN 12 Malang. Malang : PTI UM

Mayasari, P., Halim, A., Ilyas, S. 2013. Model Pembelajaran Creative Problem Solving untuk Meningkatkan Penguasaan 
Konsep dan Keterampilan Generik Sains Siswa SMP. Vol (1) No 1. Tersedia di http://www.jurnal.unsyiah.ac.i d/ JPSI/article/view/983

Mutiara, C. \& Suyanto, E., Abdurrahman.2014. Pengaruh Kinerja Belajar pada Model Pembelajaran Creative Problem Solving terhadap Hasil Belajar. Vol (2) No 6. Tersedia di http://webcache.googleuserco ntent.com/search? $q=$ cache:http://jurnal.fkip.unila .ac.id/index.php/JPF/article/vie w/5906

Purnamasari, O.I \& Putro, S.C. 2012. Pengaruh Faktor Keaktifan dan Variasi Metode Pembelajaran terhadap Hasil Belajar Dasar Pemrograman Pascal. Vol (17) No.1. Tersedia di journal.um.ac.id/index.php/tek no/article/ view/3365/4336

Putro, S.C. \& Desynatria, W. 2016. Interaksi antara Faktor Inisiatif dengan Faktor Penerapan Model Konstruktivistik Pengaruhnya terhadap Hasil Belajar Teknologi pada Siswa SMK. Vol 26 No 2. Tersedia di http://journal.um.ac.id/index.p hp/tekno/article/view/8274/38 $\underline{05}$

Sukakara, B. 2017. Group Investigation untuk Meningkatkan Hasil Belajar Mata Pelajaran Teknologi Informasi dan Komunikasi Kelas VII di MTs Al-Istiqomah Rungus Kabupaten Madiun. Malang : PTI UM
Sugiyono. 2015. Metode Penelitian Pendidikan. Bandung : Penerbit Alfabet

Supriadie, D., Darmawan, D. 2012. Komunikasi Pembelajaran. Bandung : PT. Remaja Rosdakarya Offset

Totiana, F., Susanti, E., Redjeki, T. 2012. Efektivitas Model Pembelajaran Creative Problem Solving (CPS) yang Dilengkapi Media Pembelajaran Laboratorium Virtual terhadap Prestasi Belajar Siswa pada Materi Pokok Koloid Kelas XI IPA Semester Genap SMA Negeri 1 Karanganyar Tahun Pelajaran 2011/2012. Vol (1) No 1. Tersedia di http://jurnal.fkip.uns.ac.id/ index.php/kimia/article/view/1 156/1387

Wildanisnaini, Susanti, E., Haryono, H. 2015. Penerapan Model Pembelajaran Group Investigation (GI) untuk Meningkatkan Keterampilan Proses dan Prestasi Belajar Siswa pada Materi Laju Reaksi Kelas XI SMA Negeri 2 Karanganyar Tahun Pelajaran 2013 / 2014. Vol (4) No 1. Tersedia di https://anzdoc.com/faxb9591d07fdde00808ad6d934f6 de09f188122.html 